\title{
ISLAMIC STUDENTS, ENVIRONMENTAL DEVELOPMENT AND PARNERTSHIP: STUDY ON ASSOCIATION OF ISLAMIC STUDENTS IN INDONESIA
}

\author{
Ismail Suardi Wekke \\ Faculty of Education, Universiti Kebangsaan Malaysia \\ Email: iswekke@gmail.com \\ Natsar Desi \\ Universitas Indonesia, Indonesia \\ Email: natsardesi@gmail.com \\ Maimun Aqsha Lubis \\ Faculty of Education, Universiti Kebangsaan Malaysia \\ Email: $\underline{\text { mal@ukm.my }}$
}

\section{PRESENTED IN}

The International Conference on Youth Research 2008 (ICYR 08)

Developing a Global Generation : Directions and Challenges

Putrajaya, Malaysia, 16-17 December 2008

\begin{abstract}
In regard to Islam, Indonesia as the largest Muslim democracy in the world, the location and power of youth present a unique experience to form professional relationships, develop projects and advance policies that are vital for national security and human well being in term of environmental development. This paper addresses some of practices of Islamic students which a part of environmental improvement and partnertship mainly derived from their youth spirit. In addition, it also aims to explore actual experience with regards to contribution within the organizational context. The study performed in Himpunan Mahasiswa Islam (HMI, The Association of Islamic University Students) in Indonesia. They live out on experiential learning approach to explore opportunity to participate on sustainable city growth. Data was collected through interviews with 25 number of informants and documents on many activities and series of environment agenda. They are part of Pengurus Besar (national board) in Jakarta. The respondents were asked to define their organizational policy on environment and natural resources. At the same time, they were also asked to describe their experience in their projects. Respondents' descriptions of their experiences on the project work were compared to one another, even though they are engaged to the same type of projects. Students' experience of program on environment is undeniably important in enhancing a better performance on national progress. With such experience in hand, they will contribute towards a better atmosphere. The programs enable students to present their spirit and power in building better environment.
\end{abstract}


Additionally, programs provide a platform for dialogue and the exchange of ideas. They bring forward voices from cultures and situations that are typically not included in environment discourses, to empower local communities and to build a national community that promotes environment policy and action. The paper concludes with a number of implications and research direction to enrich the knowledge of student participation in the development sustainable cities. They expect to explore in a setting conducive to constructive involvement and also grapple with the challenges associated with non-violent social change.

\section{INTRODUCTION}

It is extremely difficult to identify the role of the student organization in developing students' knowledge, concepts and attitudes as opposed to influences from other agents of socialization like the media, peer groups and parents. Students themselves state that the school has been important for explaining concepts of daily life, for its democratic environment and for teaching tolerance and cooperation, but less important in terms of influencing them to participate in public policy issues and organization that involve on government or politics.

Organizational climate seems to be an important variable for developing attitudes, establishing concepts, knowledge and skills. There is a strong positive difference between organization and classroom as learning medium that an organization climate characterized dialogue, discussion and exchange of arguments on the one hand, and the student's profile of knowledge and attitudes on the other. This is internationally valid, and it seems to be the case in Norway to an even stronger extent. This outcome is foreseen by an American researcher (Hahn, 1998). She points out that there are strong arguments suggesting that the Nordic schools are especially skill full in working with organization climate.

Islam in Indonesia, which has about 230 million people which subscribes to Pancasila (five pillars of state-ordained ideology) as the state philosophy, while major Islamic organizations (Muhammadiyah, Persatuan Islam and more) have colour the face of Indonesian Islam. The student movements have played an important role in shaping religiosity of contemporary Indonesia. Student organization development is dynamic and changing according to local and global contexts; its political programs are not necessarily "extreme" when compared to the Taliban in Afghanistan or other reactionary groups elsewhere. A few publications have also been promoting more colourful interpretations of Islam. In addition, TV programs and art performances show a combination of tradition and modernity. Modern and post-modern cultures using Islamic themes are also present. The struggle also continues against such problems as social injustice and human rights violations. One thing is for sure however: The struggle of Islam will continue within a diversity Indonesia and in a changing world. 
One of the greatest challenges in student organization is how to ensure that young people are passionate about causing transformation in Indonesia. University students as youth are the instrumental force for causing such transformation. Young people need a youth branded platform from where they can speak powerfully, take appropriate action and inspire belief that will have a catalytic impact all over the country through youth-led development initiatives.

HMI (Himpunan Mahasiswa Islam/The Association of Islamic University Students) seeks to be one of the student organization working in the field of environment in Indonesia levels through environmental program; That offer an integrated services and activities towards the environment protection and conservation, capable to provide full enabling to its beneficiaries. HMI is a student run and student led national network of progressive organizations and individuals whose one of the aim is to uproot environmental injustices through action and education. They are in 164 branches and 14 regional coordination board throughout Indonesia.

This paper explores the programs about students' participation in environmental development in Indonesia since the 1999 when they appointed a deputy in the national board to address environment and natural resources. Before 1999, they integrated to human rights department in regarding environment. This is consistent with environmental education guidelines that emphasize knowledge and skills that students grappling with environmental issues may develop understandings of environmental science and political processes and skills in scientific inquiry and civic engagement, all of which are crucial to participation in a democratic society (Paxton \& Kunovich, 2003). We then draw from students activities to describe youth participation in local and national environmental action. In addition, it is a portrait of practice of engaging youth in action to improve their local and national environment, providing opportunities for science and civic learning.

\section{THEORETICAL FRAMEWORK AND METHODS}

We used qualitative research methods based on document analysis and interviews of relevant actors in analysing the participation of the Islamic student organization on the environmental program process. The document analysis was based upon policy documents and official reports of the organization the period 1999-2007. The interviewees were visited in their offices and program places. They were asked about their opinions and experiences concerning the program on the environment and were invited to speak as openly as possible by assuring their anonymity, particularly of those working within other groups. The content of these interviews was analysed by categorizing experiences, opinions and statements about important contextual elements such as political issues. These categories were compared with findings from reports, studies and documents. 
This paper focuses on student's conceptions of environment and attitudes toward political participation in environment, without an a priori acceptance of the relevant categories that prevail in the literature. Our intention is to allow differentiated interpretations of the meaning constructed by students (Torney-Purta, Schwille, \& Amadeo, 1999). We try to expand the study's implicit Weberian view that "the social world with its meanings and roles is the result of shared construction of meaning by individuals" (Kolb, 1986:9). We also attempt to explore differentiated meaning construction and to allow for equal examination of student views which express both known and well-described categories of public policy and environmental participation, as well as "unknown" and "undescribed" views. This examination is based on grouping students according to their cultural capital.

In spite of a growing lobby in favour of students' rights to participate, there remains intransigence in some quarters about whether such political involvement is appropriate. Lansdown identified three reasons why some adults are reluctant for students to take part in decision-making that will impact on their own life and the lives of others (Lansdown 1995:20). First, giving students the right to say threatens the harmony and stability of family life by calling into question parents' "natural" authority to decide what is in the best interests of a youth. Yet, as Qvortrup et al., (1994) suggest, to sustain such an argument, it must be beyond reasonable doubt that adults behave with students' best interests in mind. In practice, this is not always the case. Second, imposing responsibilities on students detract from their right to childhood, a period in life which is supposed to be characterised by freedom from concern. Such a perspective ignores the fact that many students' lives are full of legitimate concerns which are products of the same social and economic forces that affect adults. A third strand to the argument is that students cannot have rights until they are capable of taking responsibility. This view is based on an idealised view of childhood, yet few students as children live without responsibilities. Alanen (1994) points out those students' activities and duties within the home are underestimated, whilst the reality of schoolwork and its associated responsibilities are rendered invisible by the label education.

Unlike other marginalised groups, however, students as children are not in a position within most western societies to enter into a dialogue (with adults) about their environmental concerns and geographical needs. In this sense, students occupy a special position of exclusion. Their ability to challenge the conventions of dominant ideology from within, together with the practices and processes which lead to their socio-spatial marginalisation, is mostly beyond their grasp. Students as "outsiders" need allies with its concern with the politics and power of space and spatiality (Painter and Philo, 1995) is well positioned in this respect. Younger citizens are unsettled and have not yet developed a habit of voting whereas the middle aged and elderly have (Deufel, 2002; Plutzer, 2002). A generational effect, on the other hand, is indicative of differences between generations when the comparison cohorts are at similar stages in the lifecycle. 
The political doctrine of nationalism is based on the idea of a nation or a people and it usually locates an 'other' who is used to reinforce ties uniting the nation. In other words, a coherent community exists because "we" are ethnically, linguistically, religiously and/or ideologically distinct from "them.' It has become a truism to acknowledge that nationalism, in the oft-quoted words of Anderson (1991), is imagined. The theoretical rooting of the process of nation building in imagination denies malicious intent to deceive or falsify, but rather highlights the creative attempts on the part of communities to build an intersubjective identity marked by common cultural myths, symbols, heroes and heroines.

Furthermore, students would be counted as social capital. Social capital, which describes parts of the social context, is associated with different outcomes such as experiential learning (Kawachi \& Kennedy, 1997; Kawachi et al., 1999). It is defined as interpersonal trust between citizens, group membership that facilitates collective action and cooperation for mutual benefit, norms of reciprocity and density of civic associations (Sampson, 1988; Putnam, 1993; Kawachi et al., 1999a, b). Social capital has often been operationalised as social participation, i.e. formal and informal networks.

\section{HIMPUNAN MAHASISWA ISLAM (THE ASSOCIATION OF ISLAMIC UNIVERSITY STUDENTS)}

On the development of modern Indonesian politics, HMI (Himpunan Mahasiswa Islam), founded in Yogyakarta in February 5, 1947, is one of the greatest student organizations training many activists. National commitment of HMI is not merely slogan since in its first anniversary in 1948, the Chief Indonesian army force, general Soedirman, considered HMI as a new shining hope for Indonesia people. Even a year after, an Indonesian Moslem congress in Yogyakarta confirmed that HMI was the only student organization existed at the time. In earlier developing stages, HMI had not, of course, become an organized, systematized and structured cadre organization as that of modern ones. This was mainly caused that HMI had to participate in the physical struggle at defending the independence of the state and also consolidating after the independence. Ismail Hasan Metareum (1997:36) insisted that in the time of revolutionary period for independence and organization consolidation, cadre-forming process of HMI still relied on the hidden curriculum and unclear model. The process began to consider in the face of 1955 general election, in which HMI kept distance with the dynamic of practical politic of parties mushrooming by the first democratic general election. In this case, HMI conference in Kaliurang on April 1955 confirmed that when an HMI member was elected into constituante (people representative), he had to resign his office from HMI.

HMI strategic position as a student organization founded two years following Indonesia independence, producing many cadres serving various strategic positions in both government and private sectors. This strategic position of cadres, of course, will influence decision taking of power politic (Hasanuddin M. Saleh, 1996:30). HMI is not political organization, but it puts 
concern on the political issues that make HMI accused as pressure group and environment is a part of public policy to concern. HMI though is not only intense in the issues of intellectuality, Indonesianism and Islamism but sometimes it also engages in political roles that can ultimately create new problems for it (Masykur Hakim, 1998).

Hasanuddin (1996) in his study has proven the significance of HMI cadre forming in militancy, ideology and thought. This conclusion was based on some reasons. First, HMI is a huge student organization, which is able to move the mass in a time. Second, HMI is a student organization founded two year following Indonesia Independence, which has producing many successful cadres to serve both in government and private sectors. This ultimately enables the cadres to influence political policies in all levels of political structures.

One of the main activities is the engagement in environment issues and promoting sustainable environment by mobilizing youth to undertake community services like clean up exercises, afforestation/reforestation, erosion control and providing education on environment to various communities.

\section{FINDING}

HMI has established a watchdog network to monitor the work of environment activities. In recent years, non-government organizations have played a key role in organizing and mobilizing local communities, usually around environmental issues. HMI movement has become more institutionalized in recent years; many prescribe cookie-cutter solutions to problems that require more exacting localized solutions. To remain responsive locally, it is crucial for community movements to stay small, local and free of the strictures of over-institutionalization.

Environment department is to make sustainable development a reality by helping Indonesian live and prosper in an environment that needs to be respected, protected and conserved. They do this by working to preserve and enhance the quality of the natural environment (including water), preserving renewable resources (including flora and fauna), conserving and protecting water resources.

The numerical strength of the young people offers a great resource not only for the care of the environment but also provides the potential to re-afforest Indonesia. In recognition of this fact, strategies that will address the problem of environmental degradation will be commended. HMI facilitate and promote the formation of environmental clubs for the youth, strengthen the

involvement of the youth in environmental conservation programmes and encourage the use of alternative sources of energy to protect forests from destruction. 


\section{Engaging Youth and Mainstreaming Environment}

Young people can play an important role in development if provided with the right tools, learning and empowerment to employ those tools and a supportive environment in which to use them. Recognizing this potential, it is critical that in pursuing the sustainable development on environment, HMI include youth in all aspects of participation.

They have begun promoting the engagement of youth in environmental initiatives and incorporating environment into on-going youth activities within the government agencies and beyond. The members of HMI are actively collaborating with existing youth programs in the Indonesian government from local to national level and development partners to strengthen these agenda by promoting the inclusion of environmental sustainability in one of the priorities being addressed by youth programs.

\section{Student Participation in Recycling}

In this study, to obtain basic information to determine the priority of political measures such as the raising of awareness, the provision of information and improvement in collection services, they constructed predictive models for recycling behaviour and extracted predictive factors that have a significant impact on behaviour. In addition, by conducting sensitivity analyses of the predictive models, the degree to which the students' participation rate changed with the change in the contents of political will was estimated to encourage society to involve at that program, as was the associated effect on the reduction in environmental load.

To establish a sustainable society, it is essential to comprehensively institute various measures, including the reduction, reuse, recycling and proper processing of waste, as well as obtaining the cooperation of citizens. A team work in charge of waste treatment should assess the environmental load imposed by such measures and the extent to which it can be reduced, thus initially forming a clear picture and then creating and implementing comprehensive measures to decrease the environmental load efficiently. To effectively secure the participation of citizens in the separate collection of recyclable waste, which is crucial in promoting recycling, appropriate measures, should be taken. The cooperation of citizens which to support students program in the separate collection of waste is affected by various factors, including the level of collection services and the degree of public awareness of environmental and waste problems. Finally, students' forces are promoting and driving many campaign events to socialize this program.

\section{Education and training}

The educational activities are important in raising environmental awareness among the students. Unfortunately, they often do not possess the necessary skills to undertake this kind of reporting 
in an effective way. Therefore, HMI organize regularly training both in long term and short term to provide partial support for a workshop to help increase the abilities of students to report on environmental issues in a more comprehensive and understandable manner. Specifically, it will support the participation of 164 organization branch to write any documents and produce programs on the environment in a workshop; and provide these students with background information and documentation on environmental issues and train them on how to acquire and use additional information on a regular basis.

In line with its responsibility to consult with it's culturally and religiously, the HMI hosted over 200 delegates from academic and private sector organisations every six months. This training, promoting cultural harmony, had a strong youth focus, with many workshops led by professional and outstanding students with many supports from government and NGO.

The training aims at offering the possibility for students to improve their skills in environmental science. Any student from different institution can qualify. To be accepted, a potential participant will need to demonstrate previous interest in covering environment issues as well as a willingness to improve his or her skills in environment and public policy. The greatest outlook is advocating society in taking part on environmental issues.

\section{Protecting Water from Mine Waste}

Mining produces large quantities of waste rock, tailings and other refinery by-products that are usually stored on site. With exposure to the atmosphere, the sulfide-rich waste oxidizes, releasing acid and metals into the environment and putting nearby water bodies at risk. Student working group are leading studies on the mechanisms that control the release and transport of these contaminants-information needed to develop effective management and restoration strategies. In addition, they work on maintaining the industries to run on the regulation.

HMI researchers and their partners are carrying out their investigations at several Indonesian sites, including the Sidoarjo, Buyat, Mataram and Soroako. To find out what is happening below the surface, the researchers collected continuous cores of the tailings, coring from the surface to the bottom of the tailings piles. The research team's results provide irrefutable evidence that abandoned mines can continue to release elevated concentrations of metals and other elements to surface and groundwater long after they are closed. After seven cohorts of oxidation, the pore waters in the tailings contain very high concentrations of dissolved metals, sulfate and acid. Nearly all of the neutralizing minerals have been depleted, but less than half of the sulfidemineral content has been consumed - suggesting that metals and acids will be released for decades or possibly centuries to come.

Results of these studies will be used to push industries to improve their models for predicting the duration of the oxidation process, the rates at which metals are transported, and their long-term 
release into receiving waters. More accurate predictions of the degree of environmental damage likely to occur and how it can be avoided through improved disposal methods will lead to more effective tailings management programs and a more sustainable mining industry.

\section{ANALYSIS AND DISCUSSION}

Greater Islamic students' involvement in public policy especially in environment making adds further complexity to the process of decision making by increasing the potential for conflict about the nature of the problem. This give rise to dilemmas concerning the extent of public involvement in the process and the weight given to inevitable differences in values resulting from greater involvement, here called the dilemmas of voice and values. The case study describes a situation involving a large number of students in a process that makes use of the values graph in order to manage the many voices and values throughout the decision-making process and allows differences in value priorities to be kept visible. A key objective of the approach was to ensure that all voices were heard and the full range of values explored. At the start of the work there was concern that, because there was a heavy weighting of representatives from statutory agencies, alternative views may not be considered. In fact, alternative and minority interests did come to the fore and even the ones that might have threatened the process were addressed.

Although it may be difficult to make conclusions in the absence of a full evaluation, it was observed that a great deal of the success of the process was in part due to the flexible and adaptable nature of the mechanisms introduced and to the attention given to different voices and values which was explicit from the outset. The experience points to the need to approach the process of working with large and diverse groups of people in an inventive manner. The case study indicated that students have different power bases yet at the same time share an interest in the process. Adopt a more formal analysis of power and interest in order to prevent the decisionmaking process being blocked by stakeholders exercising a veto, in this study a more implicit approach was adopted. This process ensured that policy was informed by the community as well as by organised interest groups. In the workshops it was found that power and interest were contained. It would be interesting to compare this outcome to the kinds produced by stakeholder analysis used in other processes (Bryson, 2004, Eden, 1998 and Checkland, 1990).

HMI and Indonesia has experienced important milestones in the environmental field yielding precious lessons learned to proceed further in the development. Firstly, they have joined the urban millennium, where towns and cities will be met with continued rapid population and economic growth. This will be accompanied by significant urban expansion with its excessive energy and resources consumption, in the expense of natural resources, natural ecosystems and environmental problems. It is also noted that in the future, the low and middle-income population group will be the most significant factor at shaping the outcome of urban-living in our country. 
How they manage that population growth and our behaviour in respect to the environment and architecture disciplines will be crucial toward influencing future livelihoods and prosperity.

Secondly, the devastating earthquake and tsunami of 26 December 2004 in Aceh and Northern Sumatra give them new insights and made them realize that we always live in the shadow of natural disasters. Now the society fully appreciate that all living things play an important part in the prevention of natural calamities. The functions of the environment itself can be used as a tool to prevent or at least mitigate the effects of future disasters. An example of this would be to utilize natural ecosystems as barriers and damage-minimizing factors. In addition, the tsunami has raised environmental concerns that threaten human health. Moreover, the need for continuous livelihood became more urgent. These are the lesson learned and it would be irresponsible if they were not included in the total concept of environmental development planning.

Through civic engagement young people can develop understanding of concepts and gain skills, including those related to political knowledge, critical thinking, communication, public problem solving, civic judgment, civic imagination and creativity, community/coalition building and organizational analysis. This learning, in turn, can increase young people's ability to exert influence in public affairs through enabling them to play an informed and active role in the political systems of power and decision-making, to make choices rather than accept the prescriptions of others, to hold experts accountable and to insert their own knowledge into the public discourse.

In Indonesia, university student groups have repeatedly been the first groups to stage street demonstrations calling for governmental change at key points in the nation's history and other organizations from across the political spectrum have sought to align themselves with student groups. Thus, the student movement is important because it has been made an important character in an important narrative tradition. The heroic tales of intellectuals and their activities in the past function as models and incentives for the intellectuals who receive them. So a mythology is strengthened by a concrete empirical reality. At the same time, those outside the category of 'students' find themselves urged to adopt, to discuss, to report and to conceive of the activities of present day students within the framework of the already established historical narratives. And so the circle is closed, a blend of fact and fiction, narrative and event.

\section{CONCLUSION}

Environmental education practice often focuses on personal responsibility and promoting environmentally-conscious individual lifestyle choices but inadequately addresses economic and political structures that limit individuals' freedom to make those choices. Therefore, it's a big 
step to involve student in creating activities to support environmental program. The action is also intended to achieve a specific positive environmental outcome, either small or large. Participation in local environmental action, which occurs at the intersection of ecological, economic, social and political systems, provides opportunities for integrating science and civic education.

This is consistent with environmental education guidelines that emphasize knowledge and skills in both science and citizenship. Youth grappling with environmental issues may develop understandings of environmental science and political processes and skills in scientific inquiry and civic engagement, all of which are crucial to participation in a democratic society. The student movement in contemporary Indonesia has yet to maximize the power of cultural change, because it has taste for cultural politics. This in turn is the result of at least two factors. The first is the conservative understanding of culture and cultural analysis that has been central to the system of state education in Indonesia since colonial times. The second is the antagonistic view

of culture in the leftist paradigms of the 1970s and 80s. In short, all societies know about culture is limited to what aristocratic/feudal and bourgeois/modern ideology understands of the term.

\section{FUTURE RESEARCH}

The study about religious values including their interpretation by students' leader will also need to be conducted. Since organization based on Islamic values, studying how people interpret Islamic teachings connected to environmental issues is important. Therefore, studying student leaders' behaviour and their role in the society is very useful to understand religious influences in the society. The Islamic (university) student organization fills an important function in an impoverished country such as Indonesia, where higher education is available only to a few and can not provide many opportunities to learn. Today, there is an estimated 100,000 student activist in Indonesia.

\section{REFERENCE}

Alanen, L., (1994). Gender and generation: feminism and the child question. In: Qvortrup, J., Bardy, M., Sgritta, G., Wintersberger, H. Aldershot:Avebury Press.

Anderson, B. (1991). Imagined communities. London: Verso.

Bryson J. (2004) Strategic planning for public and nonprofit organizations. San Francisco: Jossey-Bass.

Checkland P, S. J. (1990). Soft systems methodology in action. Chichester: Wiley.

Deufel, B. J. (2002). The Peter Pan Effect: why young people are voting less today. Paper Presented at the Annual Meeting of the Midwest Political Science Association, Chicago, IL, Palmer House Hilton, April 25-28, 2002.

Eden C, A. F. (1998) Making strategy: the journey of strategic management. London: Sage 
Publications Ltd.

Hahn, C. (1998). Becoming political: Comparative perspectives on citizenship education. Albany: State University of New York Press.

Hasanuddin M. Saleh. (1996). HMI dan Rekayasa Asas Tunggal Pancasila. Yogyakarta:Pustaka Pelajar.

Ismail Hasan Metareum. (1997). Penegakan Jiwa Kemandirian dan Kepeloporan HMI, in 50 Tahun HMI mengabdi Republik, Ramli HM. Yusuf, (ed). Jakarta: LASPI.

Kawachi, I., \& Kennedy, B. P. (1997). Health and social cohesion: Why care about income inequality? British Medical Journal, 314(7086), 1037-1040.

Kawachi, I., \& Kennedy, B. P., et al. (1999). Social capital and self-rated health: A contextual analysis. American Journal of Public Health, 89(8), 1187-1193.

Kolb, D. (1986). The Critique of Pure Modernity. Chicago: The University of Chicago Press.

Lansdown, G. (1995). Taking Part: Children's Participation in Decision Making. London:IPPR.

Masykur Hakim. (1998). The Response of Muslims Youth Organizations to Social-Political Change: A Case of HMI Role in Indonesia. India:Jamia Millia Islamia.

Painter, J., Philo, C., 1995. Spaces of citizenship: an introduction. Political Geography 14, 107120.

Paxton, P. \& Kunovich, S. (2003). Women's political representation: The importance of ideology. Social Forces, 82(1), 87-114.

Plutzer, E. (2002). Becoming a Habitual voter: inertia, resources and growth in young adulthood. American Political Science Review, 96(1), 41-56.

Qvortrup, J., Bardy, M., Sgritta, G., Wintersberger, H. (Eds.). (1994). Childhood Matters: Social Theory, Practice and Politics. Aldershot:Avebury Press.

Sampson, R. J. (1988). Local friendship ties and community attachment in mass society: A multilevel system model. American Sociological Review, 53, 766-779.

Torney-Purta, J., Schwille, J., \& Amadeo, J. (1999). Civic education across countries, case studies from the IEA civic education project. Delft, Netherlands: Eburon. 